\title{
Gender and Sexuality in Medieval Islamic Mysticism: A Comparative Study of Ibn 'Arabi and al-Ghazali
}

\author{
Emily Dovel* \\ History Department, University of Portland, Portland, OR \\ Student:dovel16@up.edu* \\ Mentor:franco@up.edu
}

\begin{abstract}
Mysticism, defined as a direct experience with God that cannot occur through intellectual knowledge, has the potential to offer women opportunities disallowed by a patriarchal society. Because mysticism exists outside of religious institutions and hierarchies, female mystics could receive opportunities for public expression often prohibited by Medieval Islamic societies. Islamic Mysticism, or Sufism, has a long history of prominent female mystics. However, Sufi thought in the $12^{\text {th }}$ and $13^{\text {th }}$ centuries was certainly affected by the misogynistic influences of the greater society. In order to explore the ideological conflict within medieval Sufism, between the potential for gender egalitarianism within mysticism and the influences of patriarchy, this paper examines the theology of two prominent Sufi mystics, Ibn 'Arabi and al-Ghazali, and proposes some explanations for the large disparity between the two Sufis' opinions on gender and sexuality.

Specifically, al-Ghazali fully supports the subjugation of women, and even equates the perpetuation of patriarchy to religious piety. This paper argues that, living under the politically turbulent and authoritarian reign of the Seljuks in Iraq, during the late $11^{\text {th }}$ and early $12^{\text {th }}$ centuries, al-Ghazali was particularly disinclined to question traditional orthodoxy, particularly with regard to gender. Ibn 'Arabi, by contrast, accepts the spiritual, intellectual, and legal equality of women to a remarkable extent. Raised in Muslim Spain in the late $12^{\text {th }}$ and early $13^{\text {th }}$ centuries, Ibn 'Arabi was exposed to female mystics as teachers and experienced little political pressure to conform to traditional doctrine. Further, Ibn 'Arabi subscribes to Oneness of Being theology in which the created, material universe is an emanation of God, and is ultimately part of the same divine being. As such, unlike many religious thinkers within patriarchal societies, who tend to reject worldliness_along with women and female sexuality-in an attempt to reach God, Ibn 'Arabi believes that all things material—including women and the human body_are ultimately connected to divinity
\end{abstract}

\section{KEYWORDS}

Islam; Sufism; Gender; Sexuality; Theology; Medieval History

\section{INTRODUCTION}

Celebrated $13^{\text {th }}$ century Muslim mystic Ibn 'Arabi once wrote, regarding one of his female disciples, "I wrapped her in the raiment of piety, / That raised her above gender." "He was suggesting, like many mystics in the Islamic tradition, that true devotion to God outweighs gendered human constructs of value and power. Mysticism, defined as direct experience with God, often has dimensions independent from traditional religious hierarchy. As a result, mysticism has the potential to offer women an opportunity for a voice of authority when dominant religious institutions reject or silence women's voices. ${ }^{2}$ The Islamic mystical tradition, called Sufism, was particularly prominent throughout much of the Middle Ages and frequently held women in high regard. From its beginnings, Sufism recognized many prominent female mystics within its ranks. As a result, Sufi ideology tended to contain more egalitarian thought than was allowed by orthodox theologians. Women were often barred, by tradition or law, from participating in the normative religious practices which occurred in mosques. However, neither tradition nor law could prevent women from claiming a special connection with God through mystical experience.

At the same time, Sufi theological and philosophical thought was certainly never exempt from influences of androcentric interpretations of holy texts; indeed, like in most major religions, men in both Sufism and Islam most often interpreted and applied religious doctrine in such a way as to privilege the male gender. Nor was Sufism exempt from the rampant misogynistic discourse in both legal and political realms, which could be distrustful or outright hostile towards women. Sufi mystics were often respected members of the community, well integrated into normative society. As such, they were undeniably susceptible to the cultural prejudices and patriarchal assumptions of the Medieval Islamic world. Further, Sufism had a powerful ascetic strain, and as a result, tended to associate women with worldliness, sexual temptation, and distance from God. ${ }^{3}$ Medieval Sufism, therefore, represents a fascinating area of conflict between the patriarchal influences within normative Islamic theology and the inclination 
often found within mysticism to reach God through transcending human power constructs. By studying gender ideology within Medieval Sufism, historians can better understand the ways political power, religious authority, traditional interpretive doctrine, and individual experiences with the divine, affect the extent to which gender norms are reinforced or challenged.

Through an examination of two exceptionally prominent Sufi thinkers of the $11^{\text {th }}-13^{\text {th }}$ centuries, this paper investigates the tension within Sufism, between the influence of misogyny often prevalent in mainstream Medieval Islamic theology and the influence of Sufi mysticism, in which female mystics derived voices of authority directly from God. Sufism has the potential to radically challenge power structures and value assumptions created by humans, including those of patriarchy. However, when Sufi thought is absorbed into orthodox theological discourse, and the propaganda of political authorities interested in preserving the societal status quo, it can become a powerful tool for reinforcing prevailing gender ideology. This is the case with one of the most widely read scholars in Sufi history, Abu Hamid Muhammad ibn al-Ghazali. As a highly educated theologian and teacher, fully ensconced in both theological orthodoxy and systems of political authority of the late eleventh and early twelfth century Near East, al-Ghazali endorsed and perpetuated the dominant orthodox tradition with regard to gender. His Sufi theology does not question patriarchal discourse, but reinforces traditional gender norms. Indeed, al-Ghazali advocates for a system of behavior which requires devout men and women to perpetuate patriarchal power dynamics in order to live truly pious Muslim lives. His writings on gender in the Ihya' Ulum al-Din (The Revival of Religious Sciences) provide an excellent example of the extent to which mysticism can reinforce normative power structures, including that of patriarchy.

In contrast to al-Ghazali, another prominent mystic in Sufi history, Andalusian Sufi master Abu 'Abd Allah Muhammad ibn 'Ali ibn Muhammad ibn 'Arabi al-Hatimi at-Ta'i, never succumbed to pressure from either orthodox theological authorities or the political powers of Andalusia. In Ibn 'Arabi's most famous theological treatise, Fusus al-Hikam (The Bezels of Wisdom), his autobiographical work, Al-Futūhāat al-Makekiyya (The Meccan Openings) and his book of poetry, the Tarjumān al-Ashwāq (The Interpreter of Desires), he exhibits significant disregard for traditional interpretations of Qur'anic and Hadith texts, including theological discourse with regard to gender. Indeed, Ibn 'Arabi expresses remarkable support for women's participation in all aspects of religious experience. Ibn 'Arabi's educational and personal experiences with female mystics in late $12^{\text {th }}$ century Andalusia helps explain his radically egalitarian beliefs. Further, because Ibn 'Arabi subscribes to what he calls a Oneness of Being theology, in which all existence in the universe is merely an emanation from God, he avoids the misogyny which usually results from associating women with worldliness, sin, and distance from God. Ibn 'Arabi's mystical thought, largely free from the political and theological pressures al-Ghazali experienced, represents an instance in which Sufism used the authority behind mystical experience to challenge deeply held patriarchal assumptions. The divergent views of Ibn 'Arabi and al-Ghazali, on the place of women in Islam, help to illustrate the immense differences within Sufi thought. The considerable authority behind a direct connection to God can be used to reinforce normative patriarchal theological and political power structures, or it can be used to challenge misogyny and assert social justice and spiritual equality for women.

\section{HISTORIOGRAPHY}

In one of the most thorough examinations of gender in Islamic history, Leila Ahmed traced the decline of women's opportunities in the Near East, from relative freedom during the lifetime of the Prophet Mohammed and immediately after, to exceptional subjugation by the mid-ninth century. She argues that women in the tribal Near East during jabilia, and in the first few generations after the Prophet's lifetime, were largely free to contract their own marriages, own and handle property, and even had a voice in politics and religion. Unfortunately, as Ahmed puts it, "such free participation in community affairs would soon be curtailed by the formal introduction of seclusion." 4 While the Prophet's wives were the first to be restricted, seclusion and other patriarchal practices were codified into legalist Islam to such an extent that, by the beginning of the 'Abbasid Caliphate in 850 , religious authorities assumed that a patriarchal interpretation of the Qur'an was applicable in all circumstances and for all time. Moreover, with the rising wealth of the $9^{\text {th }}$ century came a thriving sex trade industry in the Near East, resulting in the severe devaluation of women. As Ahmed argues, everyone in 'Abbasid society, by "virtue of the knowledge of the ordinariness of this transaction, and for elite men in particular because of the intimate and direct level on which they experienced that knowledge, one meaning of woman in a very concrete, practical sense, was 'slave, object purchasable for sexual use."'4 The practices of polygamy, concubinage and unconditional divorce for men, Ahmed argues, all meant a significant loss of position for women in the urban Middle East. ${ }^{4}$

While more recent scholars of gender in the Medieval Muslim world complicate Ahmed's arguments to some extent, they largely agree that women lost significant opportunities as Muslim religious texts were codified into legal practices. As Kecia Ali contends, between the late $8^{\text {th }}$ century, when important legal scholars lived, and the early $10^{\text {th }}$ century, when schools of jurisprudence systematized Islamic theological doctrines, "a coherent notion of marriage and licit sexuality, centered on exclusive male dominion of female sexual capacity, emerged." 5 Laws regarding marriage, divorce, slavery, and reproduction were largely constructed so as to allow men and male institutions absolute control over female sexual and reproductive behavior. Ali further states that, while Muslim women enjoyed rights of property ownership unrivaled anywhere in the medieval world, marriage laws and customs for women closely mirrored the institution of slavery. ${ }^{5}$ 
It is important to note, as Marion Holmes Katz does, that legal restrictions on women's movement could result from an aversion to women's prominent participation in public life. She contends that women's mosque attendance throughout the $11^{\text {th }}$ century, especially in Iraq and Syria, was quite significant, and that "the most vehement and categorical prohibitions on women's mosque attendance were produced in contexts where women were highly visible."6 In other words, proscriptions against women's mosque attendance were reacting to women's significant presence. Nevertheless, throughout the $10^{\text {th }}$ and $11^{\text {th }}$ centuries, the prohibitions from legal scholars became more effective as jurisprudence placed more emphasis on sexuality. Increasingly, discourse among theologians and political authorities became more concerned with the extent to which female sexuality could distract and corrupt male worshipers. Fears surrounding women's bodies and sexuality served as a "global rationale for restrictions on women's participation in public worship."6 Further, as Katz notes, social norms, which placed a woman's reputation in severe danger if she appeared publicly, were often far more effective than legal prohibitions in controlling women's movements. ${ }^{6}$

Nevertheless, Islam has never been controlled by a single sect or institution. Although the 'Abbasid Empire is often considered to be the high point of Islamic history, the success of 'Abbasid society led to both wealth and corruption and, as a result, an ascetic backlash against rampant materialism. As such, a mystical ascetic movement called Sufism developed, which asserted the basic spiritual equality of all humans. While law, tradition, and social norms often barred women from participation in institutions of religious or political authority, mysticism provided women with opportunities for authority and self-expression through direct experience with God.7 Although Sufi thinkers were never exempt from the misogyny of the dominant society in the Near East, female mystics were important to the mystical movement from its beginnings. Significantly, one of the most important founding figures of Sufism, who is credited with changing the focus of Sufism from asceticism to divine mystical connection through love, was an Iraqi slave woman named Rabi'a al-'Adawiyya al-Qaysiyya. ${ }^{8}$ As a result of conflicting influences, between the dominant patriarchal tradition within Medieval Islamic thought, and the often prevalent egalitarian ideology within of Sufi theology, Sufi views on women and gender have always been controversial.

Sufism often offered women the opportunity for an identity beyond sexual and reproductive capacity. There is some tendency among historians to overestimate the extent to which Sufism accepted female Sufis into the mystical fold. It is true that, as Sachiko Murata states, Sufis asked "fundamental questions concerning gender within the matrix of ultimate reality." However, Murata's statement that "Islam's basic view of men and women postulates a complementarity of functions" overestimates the extent to which Islam or Sufism ever supported gender equality. ${ }^{9}$ Sadiyya Shaikh similarly, but more cautiously, argues that Sufism is critical of power configurations that assert the superiority of particular people over others, including those that value men over women, but that Sufism never unreservedly accepted women into the mystical tradition. ${ }^{1}$ The most widely published expert on Medieval Sufism, Annemarie Schimmel, argues that Sufism was at best ambivalent in its relationship with gender equality. ${ }^{3}$ Ultimately, Sufi thought on gender throughout the $11^{\text {th }}, 12^{\text {th }}$, and $13^{\text {th }}$ centuries represents a complex debate between the patriarchal outlook of dominant legalist Islam, and the potentially radical egalitarian views of mysticism. While many scholars have remarked on the significant disparities within the writings of Sufi masters on gender, a comparative work suggesting some reasons for the difference of opinion has not yet been written.

Ibn 'Arabi and al-Ghazali are two of the most prominent and widely read thinkers in Sufi history, and represent two divergent opinions with regard to the place of women in religious experience. Both Sufi masters are widely studied, by both academic scholars and spiritual seekers. However, historical examinations of both Ibn 'Arabi and al-Ghazali, tend to focus on theology and cosmology. Historians address gender much less often. Although scholars throughout the $20^{\text {th }}$ century often mentioned Ibn 'Arabi's radically egalitarian positions with regard to gender, a thorough investigation was written only recently. While Sadiyya Shaikh's important book, Sufi Narratives of Intimacy: Ibn 'Arabi, Gender and Sexuality, is a revolutionary examination of Ibn 'Arabi's thoughts on gender and sexuality, her work does not thoroughly connect Ibn 'Arabi's gender ideology to the society in which he lived. No historian has examined al-Ghazali's thoughts on the position of women in Muslim society, presumably because his thoughts on gender fail to represent an interesting departure from typical misogynistic discourse.

Analyses on al-Ghazali's philosophical theology, however, are fairly extensive. As noted by Frank Griffel, al-Ghazali is most famous for examining the major points of Greek philosophy determining which aspects were heretical to Islam and which could be absorbed by Muslim theology. ${ }^{10}$ As a result, much of the historiography related to al-Ghazali debates whether al-Ghazali should be blamed for the elimination of Greek philosophy from Islamic thought or whether he should be credited for allowing certain aspects to be assimilated into Muslim theology. ${ }^{10}$ Al-Ghazali's thought is usually situated within a debate on the influence of Greek culture within Islam and, more broadly, within discourse on the extent to which rational inquiry has a place in religion. His thoughts on women are rarely acknowledged within the historiographical debate on gender in Medieval Islam.

Historians have written a great deal more on Ibn 'Arabi’s views on gender and sexuality. Henry Corbin, the first Western historian to examine the works of Ibn 'Arabi, provides a thorough investigation into 'Arabi's cosmological philosophy, even examining 
'Arabi's theory that a feminine element of God, namely Compassion, is responsible for creation. ${ }^{11}$ Corbin's work was later criticized, as he seems to use Ibn 'Arabi for his own larger philosophical project, without addressing how the Sufi master might have fit into broader trends within Sufi or Islamic thought. ${ }^{2}$ More recent scholars, among them Binyamin Abrahamov and Denis McAuley, theorize about the influences of various thinkers on Ibn 'Arabi. Abrahamov analyzed 'Arabi's attitude toward various Sufi masters and the extent of their influence on him. ${ }^{13}$ McAuley argues that Neoplatonic ideas reached Ibn 'Arabi indirectly, and influenced the Sufi master's theology. ${ }^{14}$ The most thorough and widely cited examination of Ibn 'Arabi's writings, by William Chittick, provides an investigation into the theological and philosophical beliefs of this great Sufi Master, but rarely mentions women or gender in 'Arabi's broader cosmological view. ${ }^{12}$ Claude Addas' important biography, by contrast, successfully examines Ibn 'Arabi's life within the context of Andalusian society, but does not draw any conclusions about 'Arabi's cosmology and rarely mentions the place of female saints either in 'Arabi's writings or in Muslim Spain. ${ }^{15}$

Most relevant to this project, however, is Sadiyya Shaikh's work on Ibn 'Arabi's gender philosophy and its potential applications for Muslim feminism. With the stated purpose of using 'Arabi as an important Muslim authority to help endorse ethical feminism within Islam, Shaikh thoroughly examines Ibn 'Arabi's opinions on the extent to which women can participate in religious experience and in the broader society. ${ }^{1}$ Nevertheless, Sufi Narratives of Intimacy often does not place Ibn 'Arabi's thoughts on women and gender within his societal context. As Leila Ahmed writes, "the extent to which the different mores of Arab Spain shaped Ibn al-'Arabi's different attitude to women . . . has yet to be explored."4 Further, historians have not yet connected Ibn 'Arabi's tendency to question orthodox theology and political power structures to his egalitarian thoughts on gender and sexuality.

\section{ABU HAMID AL-GHAZALI}

Al-Ghazali's theology of gender is quite different from Ibn 'Arabi's. Although Sufi theology throughout its long history often questioned dominant institutions of authority within Islamic society, even to the point of challenging gender norms, some Sufi ideology, including that of Abu Hamid al-Ghazali, reinforced existing gender power configurations. Al-Ghazali's writings on gender and sexuality provide an excellent example of the ways Sufism perpetuated and strengthened dominant patriarchal ideology within a particular Muslim society. Al-Ghazali spent his life in Iraq and Syria under the political rule of the Seljuks, who conquered in 1058. With the Seljuk takeover of the Near East came, in the words of historian Hamid Dabashi, "the rapid systemization of the various modes of authority in juridical, philosophical, mystical and political domains." 16 Uprisings by the Shi'a minority, attacks from the Ismail'is in Egypt, and continued unrest from former 'Abbasid rulers, meant that the new Seljuk rulers were politically insecure, and were therefore particularly eager to solidify and legitimize their rule. ${ }^{16}$ They often did so by claiming the exclusive right to interpret and enforce Islamic orthodoxy. Heterodoxy in any form was rarely tolerated. ${ }^{10}$ As Dabashi puts it, "the more the Sunnis and the Shi'ites fought each other, the more they consolidated their respective orthodoxies against both mysticism and philosophy."16 Indeed a generation before al-Ghazali's birth, a particularly prominent Sufi mystic, al-Hallaj, was executed for heresy. ${ }^{16}$ As the Seljuks continued to solidify their authority, Sufism in the greater Levant became less likely to espouse uncontrolled ecstatic utterances, instead giving way to "cooler codifications and systemic classifications of doctrines and traditions."16 The environment was particularly dangerous for Sufi mystics, leading many to continuously prove their alignment with orthodox Islamic law and theology. ${ }^{17}$ In the words of Dabashi, "Islamic mysticism has had to respond cautiously and conservatively to the violent reactions of jurists and dogmatists to their ecstatic indiscretions." 16

Recognizing the great respect communities in the Near East had for Sufi mystics, the Seljuks also worked to absorb Sufism into larger political and theological structures, thereby controlling potentially politically threatening thought. Seljuk leaders institutionalized Sufism into orders and schools, often adjacent to the theologically orthodox madrasas. ${ }^{18}$ Eastern Sufism "manifested a progressive structurization," which began during al-Ghazali's lifetime, while mysticism in the West remained an individualized practice for centuries longer. ${ }^{19}$ As a result of Sufism developing into established orders and schools, women's access to Sufi mysticism was increasingly restricted. ${ }^{20}$ As established power structures of the Seljuk Empire absorbed Sufism, Sufi thinkers had little reason to question orthodoxy, especially with regard to gender.

As a Sufi master living in the Near East during all this political and ideological upheaval, Abu Hamid al-Ghazali would have been particularly disinclined to challenge the theological orthodoxy of the Seljuks. Moreover, before al-Ghazali converted to Sufism, the Seljuk rulers employed him as a teacher of law and theology in Baghdad. ${ }^{10}$ Although al-Ghazali refused patronage by political leaders after he began following the Sufi Way in 1095, he did not change his theological or philosophical beliefs. ${ }^{10}$ Al-Ghazali's decision to follow the Sufi path and his retreat from Seljuk politics did not mean a retreat from the orthodox theology he had been educated within. As a result, al-Ghazali's writings tend not to question existing theological doctrine or social taboos. He is even credited with integrating Sufi thought into traditional orthodox theology. ${ }^{18}$ Al-Ghazali's major work on ethics, the Ihya' Ulum al-Din (Revival of Religious Sciences) combines three traditional genres: books on Shari'ah, philosophical works on ethics, and Sufi mystical handbooks. ${ }^{10}$ As a result of this synthesis, al-Ghazali's Sufi thought often agrees with and reinforces orthodox theology. Al-Ghazali's particular disinclination to question or reject traditional thinking contributed to his thoughts on gender and sexuality, which certainly lean towards the traditionally patriarchal. 
In addition to his tendency towards normative and conservative theology, al-Ghazali's conversion to Sufism in 1095 resulted in a greater emphasis on asceticism. He rejected all worldly pleasures, resigned from his post in Baghdad, and traveled to Mecca. Because he associates women and female sexuality with sin and distance from God, al-Ghazali's ascetic thought thoroughly devalues women. For al-Ghazali, women, and particularly women's bodies, represent a threat to the religious devotion of men. As a result, he advocates for the seclusion of women in order to protect men's search for God from the nefarious and destructive influences of female sexuality. ${ }^{6}$ As such, both al-Ghazali's earlier political career-which influenced his theology towards the conservative — and his converstion to asceticism—which caused him to reject all things worldly, including women—contributed to his thoughts on the place of women within Islam. Not only does al-Ghazali fail to challenge dominant gender norms, but he uses Sufi theology and authority to reinforce and strengthen a patriarchal system. Indeed al-Ghazali believes that spiritual achievement for men entails perpetuating the subjugation of women. Further, al-Ghazali connects the piety of women to submissive acceptance within the patriarchy.

Because Al-Ghazali accepts typical patriarchal fears of uncontrolled female sexuality destroying the Godly devotion of men and the order of society, he believes women should be allowed no public persona at all. Instead, he argues that a woman "should remain in the inner sanctum of her house and tend to her spinning; she should not enter and exit excessively; she should speak infrequently with her neighbors and visit them only when the situation requires it."21 Al-Ghazali further demands that women only visit less-frequented market places and dress in worn out clothing so as not to be recognized. ${ }^{21} \mathrm{~A}$ good reputation for a woman is no reputation. Interestingly, al-Ghazali even corrects Muhammad's policies on the seclusion of women: "the Prophet permitted women to go to the mosques; the appropriate thing now, however, is to prevent them, except for the old. Indeed such was deemed proper during the days of the companions." 21 The Sufi theologian was so firmly ensconced in the extreme patriarchy of his time, that not even the practices of the Prophet compelled him to question current practice. The seclusion of women, for al-Ghazali, was necessary for the preservation of a faithful Muslim community.

While some Qur'anic verses or Hadiths could easily be read as affirmations of women's value, al-Ghazali reinterprets them in a context of a strictly patriarchal society, removing special protections for, or appreciation of, women. The Prophet famously forbade female infanticide, which was common practice in the Arabian Peninsula before Islam. While this injunction could be interpreted as an affirmation of the value of female children, al-Ghazali believed that the law existed only to encourage continued reproduction within the Muslim community, arguing that "divine legislation exceedingly made the killing of children and the burying [of girls] alive an abomination, for such acts were forbidden for the fulfilment of existence."21 Similarly, Ibn "Abbas, a companion to the Prophet and one of the earliest Qur'anic scholars, declared that "the best of this nation is mostly women," in an admiration of early Muslim women. Al-Ghazali, however, claimed "Abbas must have meant that "since sexual desire was a predominant force in the temperament of the Arabs, the frequency of marriage among their righteous men was more common." ${ }^{21}$ In other words, a nation with many women was not great because of the women, but because its men had a sufficient number of wives. Al-Ghazali was less interested in obeying foundational religious texts than in preserving gender norms within his own society.

Like many scholars in the Middle East during the early Seljuk period, and perhaps characteristic of thinkers in patriarchal systems more broadly, most of al-Ghazali's concern with the place of women relates to satisfying men's sexual desire. ${ }^{4}$ Although much early Sufi thought regarding marriage and sexuality was characterized by tension between an ascetic desire to reject all worldly pleasure and a desire to live like the Prophet, ${ }^{1}$ Sufis in the eleventh century tended to accept marriage as necessary for a true spiritual life. Al-Ghazali agreed, arguing that marriage provides men with convenient and doctrinally-approved sexual satisfaction, allowing them to devote more concentration to pious pursuits. He notes, "the corrupting factor in a man's religion lies for the most part both in his sexual organs and stomach, he can satisfy one of them by marriage."21 Ghazali provides an anecdote, in which some mystics criticize a fellow Sufi master for being married, and therefore distracted from God. This Sufi master, alGhazali reports, claimed that regular sex with his wives meant that he, unlike other worshipers, was never distracted from prayer by sexual fantasy. ${ }^{21}$ In this view, women and women's bodies become a tool used for the spiritual growth of men.

Moreover, al-Ghazali supports a marriage paradigm in which men have the unlimited right to discard their wives. He notes that "al-Hasan, the son of 'Ali, was a great lover having married more than two hundred women. Perhaps he would marry four at a time, and perhaps he would divorce four at a time replacing them with others ... It was said that his indulgence in marriage is one of the characteristics in which he resembled the Messenger of God."21 Al-Ghazali's admiration of al-Hasan suggests both that he believes marriage in extreme numbers could be compatible with a good Muslim man's life, and that he has little regard for the women affected by men's right to unrestricted divorce. In al-Ghazali's opinion, the legal system which placed a married woman at the mercy of a husband's whims was good and necessary to preserve the devotion of Muslim men. 
Further, Al-Ghazali advocates for marriage, arguing that for men marriage to women could make one a more patient and resolute Muslim because he must endure the vicissitudes of an irrational woman. Al-Ghazali thinks “toleration of a woman's tongue would try the saints," but by marrying and learning the compassion and patience necessary for living with women, a man can become a better Muslim. ${ }^{21} \mathrm{He}$ often advocates for patronizing self-sacrifice: "know ye that good conduct with her does not mean not harming her, but rather enduring harm from her and forbearance in the face of her fickleness and anger in emulation of the Prophet; for his wives used to talk back to him, and on occasion one would leave him for the whole night." 21 Al-Ghazali both perpetuates the stereotype of the irrational woman and suggests that men are the more rational, patient beings burdened with wives to take care of. He assumes that the generosity of a man tolerating his wives will ultimately benefit the man: "disciplining the self and training it to be mindful, faithful, loyal, and respectful of the rights of the wives." 21 In this model, a man's marriage is training for the stoic endurance of hardship. Al-Ghazali unites significant devaluation of women with support for marriage as an institution, thus reinforcing both pervasive misogynistic ideas about women and the existing marriage paradigm.

Similarly, according to al-Ghazali, by supporting and enduring a family, a man works for the salvation of others, thus gaining entrance into heaven for himself. Al-Ghazali even states that "bearing the burden of wives and of offspring is equivalent to jihad for the sake of God" because "the one who is preoccupied with reforming himself and others is not the same as the one who is preoccupied with reforming himself only." 21 Presumably a man, as the superior religious person, is duty-bound to drag his ignorant and impious wives up to heaven with him. Unlike prayer and religious ritual, which only benefits oneself, providing for a family benefits others: "enduring the burden of dependents, which is a form of exercise and struggle to provide for them and sustain them, is an act of worship in itself." 21 Al-Ghazali uses his authority as a Sufi master to reinforce patriarchal gender norms by connecting the traditional marriage institution to the piety of men and the male struggle for God.

Al-Ghazali further encourages devout Muslim men to enforce traditional doctrine within the home by controlling the level of education a wife can gain. The relationship between genders is one of divinely ordained domination, as "It is a man's right to be followed, not to be a follower. God has appointed men as trustees over women and has called the husband 'master." 21 Further, it is a husband's duty to teach his wives about religion, paying specific attention to enforcing orthodoxy. He should "teach her the proper beliefs of the followers of the Sunnah, to remove from her heart every innovation should she lend an ear to it, and to make her fear God should she be lax in matters of religion." 21 Al-Ghazali seems worried that women might stray from 'correct' religious doctrine, and charges the husband with eliminating divergent or heterodox thought. The lessons, moreover, are to be uncompromising. Al-Ghazali warns men against any concessions: "the woman's behavior depends on you: If you slacken her reins a little, she will run off for a long distance." 21 He also is careful to forbid women from acquiring knowledge without her husband's consent, stating "no matter how much she learns about her obligations, she should not go out to attend a dhiker nor to receive instruction in superfluous knowledge without the consent of her husband."21 When al-Ghazali connects absolute control over the education and behavior of women to the piety and religious obedience of men, he becomes part of a system which uses religious authority to enforce patriarchal values.

While al-Ghazali does provide some advice regarding the behavior of women, he is ultimately much more concerned with perpetuating and strengthening a patriarchal system than with the spiritual well-being of women. A woman's life should revolve around her husband's: "she should always observe the rules of personal hygiene, and be ready at all times for him to enjoy her whenever he wishes." 21 Obedience and sexual availability are of the utmost importance. Further, a woman's mood should be dependent on the presence of her husband. She should be "melancholy in the absence of her husband, and to return to her sprightliness and happiness in his presence." 21 This injunction has the result of preventing a woman from having open relationships with anyone but her husband. Her happiness should not be a feeling of and for herself, but her feelings should exist only to sustain the happiness of her husband. Al-Ghazali goes so far as to argue for cowardly, prideful and stingy behavior among women, because such conduct benefits a husband. A cowardly woman obeys her husband and stays in the house out of fear; a stingy woman best preserves her husband's property; and a prideful woman will not damage her husband's reputation. ${ }^{21}$ Wives should only be concerned with providing household services. He notes, "the virtuous woman who takes care of the house abets religiousness in this manner, and any disturbance of these preoccupations would perturb the heart and impede life." ${ }^{21}$ In other words, true piety for a woman is in creating an environment allowing for her husband to most effectively seek God.

Despite the overt misogyny in much of al-Ghazali's writings, it would be unwise and reactionary to judge al-Ghazali by the standards of modern feminism. He was a man of his time, unquestioningly supporting the dominant cultural discourse on gender within $11^{\text {th }}$ and $12^{\text {th }}$ century Middle East culture, but he does not conceive of the female sex as unworthy of compassion and good treatment. For example, fathers should exercise caution on behalf of the daughters they marry off, because "she becomes a slave by the marriage and cannot be freed from it, while the husband is able to obtain divorce at all times." ${ }^{21}$ He advocates for good treatment of women, but does not question the legal system which fails to enforce fair treatment for women. Al-Ghazali also recognizes the existence and importance of female sexuality, advising that "once the husband has attained his fulfillment, let him tarry until his wife also attains hers. Her orgasm may be delayed, thus exciting her desire; to withdraw quickly is harmful to the 
woman."21 Moreover, al-Ghazali cautions that "one should not be overjoyed with the birth of a male child, nor should he be excessively dejected over the birth of a female child, for he does not know in which of the two his blessings lie."21 While AlGhazali acknowledges that the system might be harmful to women, he never challenges any institutional practice itself. In the case of al-Ghazali mysticism, which had the potential to radically challenge predominant conventions within a highly patriarchal society, became a tool for political and theological authorities in the Middle East to reinforce gender norms.

\section{IBN 'ARABI}

By contrast, when Sufism was not coopted by established religious doctrine and used to perpetuate the status quo, mystical thought could be very threatening to orthodox theology and its claims to absolute truth. As a Sufi master born in Muslim Spain in 1165, separate from the political pressure put on mystics in the East, Abū 'Abd Allāh Muḥammad ibn 'Alī ibn Muḥammad ibn 'Arabī al-Ḥâtimī aț-Ṭ̂à $\overline{1}$ was one of the more revolutionary thinkers in Sufi history. Because he lived most of his life free from the political and theological pressures of dominant society, Ibn 'Arabi often demonstrates blatant dismissal for traditional dogma, even to the point of rejecting dogmatic thinking entirely. Although his thoughts on gender are certainly grounded in the context of a society which valued men over women, Ibn 'Arabi expresses remarkable support for gender equality. His disregard for traditional interpretations of religious scripture, his larger theology of Oneness of Being which values material existence, and the influences of his female teachers all help explain Ibn 'Arabi's conviction that men and women are spiritually and intellectually equal.

Modern scholars are often so impressed by the intellectual and cultural achievements of Muslim Andalusia, that they tend to graft a certain amount of gender equality onto Andalusian culture that may not have existed. However, as historian Maria Luisa Avila argues, the biographical sources from Andalusia during the Middle Ages do not represent greater opportunities for women than in any other Muslim society. ${ }^{22}$ Chronicles and biographical sources which mention women often only do so in relation to powerful men. ${ }^{23}$ Nevertheless, Sufism in Andalusia in the $12^{\text {th }}$ and $13^{\text {th }}$ centuries lacked institutional structure and proscribed regulations regarding how one could become a Sufi. ${ }^{24}$ While Eastern Sufism progressively developed more institutional structure throughout the $11^{\text {th }}$ and $12^{\text {th }}$ centuries, Andalusian Sufism remained largely an individual pursuit until much later. ${ }^{19}$ Indeed the lack of hierarchy and regulation among Andalusian Sufis helps explain why Ibn 'Arabi was exposed to several female mystics during his formative years, while al-Ghazali seems never to have considered the possibility of a female Sufi master. Because no established rules existed regarding who was to be considered a Sufi master, people who were recognized by the broader community as mystics became Sufi masters. Andalusian Sufism during Ibn 'Arabi's lifetime was not a system of institutional authority legitimized by the political powers, but was a popular movement, wherein lay people in a community decided who constituted a Sufi mystic. ${ }^{25}$ In practical terms, when mysticism has dimensions of independence for hierarchy, it is often much more open to women. ${ }^{2}$ As a result, it was not uncommon for a woman in Andalusian society to be revered as a Sufi. ${ }^{20}$

Ibn 'Arabi's biographical stories in Andalusia demonstrate both that female Sufi masters existed during his lifetime, and that Ibn 'Arabi's female teachers deeply influenced both his mystical experience and his theological opinions. Ibn 'Arabi describes one of his most significant instructors, Nuna Fatimah Bint ibn al-Muthanna of Seville, as a mystic of "profound devotion."26 She lived as an ascetic in a hut built by 'Arabi, and ate only scraps left by the community of Seville. Ibn 'Arabi considered her his spiritual mother. ${ }^{24}$ Further, the women mystics 'Arabi writes of were reportedly capable of miracles, including levitation, speedy travel, and the ability to influence politics through divine intercession. ${ }^{26}$ In his praise of female mystics, Ibn 'Arabi is firmly complementary, never suggesting that these women were spiritually accomplished despite being female. Zainab al-Qual'iyyah, a woman of reportedly great beauty and wealth, with whom Ibn 'Arabi travelled from Mecca to Jerusalem, was "the companion of many eminent men of the Folk, a" suggesting that Sufi men accepted her as legitimate. ${ }^{26}$ She was also, according to "Arabi, "one of the most intelligent people of her time."26 Similarly, a woman named Shams, Mother of the poor, had greater control over her soul than anyone Ibn 'Arabi had ever met. ${ }^{26}$ Of a slave girl from Qasim al-Dawlah he wrote "I have never seen one more chivalrous than her in our time." 26 The fact that Ibn "Arabi overtly admires the female mystics in his life, and the fact that he does not qualify his praise with 'for a woman,' suggests a complete disregard for the notion that men have greater access to God. Ibn 'Arabi's exposure to a number of female Sufi masters helps explain why he was willing to affirm the spiritual capacities of women.

In addition, Ibn 'Arabi's indifference toward traditional theological interpretations of religious texts contributed to his significant support for gender equality. While al-Ghazali uses the authority behind Sufi mysticism to reinforce orthodoxy, Ibn 'Arabi displays flagrant disregard for Islamic orthodoxy in his pursuit of mystical truth. Political authorities in Andalusian society were much more politically secure than the Seljuks in the East, and as such were much less likely to enforce traditional dogma in an effort to legitimize their rule. Although the Almohads from North Africa took Spain and attempted to set up an autocratic theocracy shortly before Ibn 'Arabi was born, the new rulers, in the words of Addas, "gradually succumbed to the seductive refinements of

a Ibn 'Arabi refers to Sufis as the Folk. 
Andalusian society."'15 While Ibn 'Arabi had close ties to the intellectual elite and official religious circles, both during his early life in Spain, and after he left Andalusia to travel in 1201, he was never financially dependent on any political figure. ${ }^{15}$ Further, because Ibn 'Arabi was raised in the more lenient Spanish society, and because he spent much of his life travelling, he was subjected to little political or theological pressure to adhere to normative dogma. As a result, traditional gender norms did little to restrict Ibn 'Arabi's theology.

A particularly vivid example of his unwillingness to conform to orthodoxy is Ibn 'Arabi's reinterpretation of the myth of Noah and the flood, in which he casts the drowned peoples, not as sinners, but as mystics. The flood story, according to 'Arabi, is a metaphor for the disagreements between those who understand God as a transcendent being unreachable to humans, and those who believe in an immanent God manifested directly into the created universe. The mystics "recoiled” from Noah's words because their inner selves were more drawn to an immanent understanding of God, while Noah only knew a transcendent and unreachable God. ${ }^{27}$ The flood waters represented, not a punishment for sin, but the gift of perplexity from God. A true Sufi experiences drowning in perplexity and confusion when he or she contemplates the paradox of a God that is at once incomprehensible and transcendent, and an immanent God that can be known through manifestation in creation. The "transgressions" mentioned in the Quranic story referred, not to sin, but to the ways mystics move beyond their own sensory reality to contemplate a greater truth. ${ }^{27}$ If God were to "deliver them [from the seas of gnosis] onto the shore of Nature He would be lowering them from an eminent state [of spiritual attainment]." 27 Ibn 'Arabi's subversive reinterpretation of the flood story exhibits both a brazen disregard for traditional interpretations of Qur'anic verse, and for the customary view of God as absolutely superior and beyond human comprehension.

Ibn 'Arabi even overtly questions the value of religious traditions, doctrines, and laws. He argues that "he who is not a gnostic calls on Him in ignorance and is bound by tradition," suggesting both a disregard for tradition itself and a belief that mystics of any religious tradition can truly know God. ${ }^{27}$ Indeed Ibn 'Arabi often implies that strict and exclusionary orthodoxy obscures truth: "One who believes [in the ordinary way] believes only in a deity he has created himself." 27 All the extra trappings of ritual, dogma and religious law which people ascribe to God are only human creation. Instead, Ibn 'Arabi recommends openness to all forms of doctrine. ${ }^{27}$ Even polytheistic idol worship is valid, because every object of worship in the cosmos contains a manifestation of God. ${ }^{27}$ Differences of religion, for 'Arabi, exist because God willed it, even though God prefers Islam. To be sure, Divine Wisdom could change Muslims to Christians at a whim. ${ }^{27}$ The perfect gnostic sees truth beyond the particulars of ritual worship and "regards every object of worship as a manifestation of God."27 Significantly, Ibn 'Arabi's apparent neglect for tradition and doctrine helps explain why he was exceptionally willing to dispute prevailing gender ideology. Ibn 'Arabi's predisposition towards disregard of the rituals, to which humans ascribe significance, meant he was not so ensconced in the dominant ideologies of his day that he could not challenge a deeply embedded patriarchal belief system.

Ibn 'Arabi, to be clear, certainly did not advocate for the abolition of legalist or orthodox Islam. On the contrary, he often emphasizes the importance of respecting both Shari'a and people in positions of authority. In his written dialogue between Moses and al-Khidr, 'Arabi demonstrates the tension between Sacred Law and mystical knowledge, noting that, while the mystic al-Khidr might have true knowledge, he is still respectful of Moses' position as representative of God's law. ${ }^{27}$ Ibn 'Arabi further believes that divine law, brought by the Prophets, is a gift to humans and is meant to be followed. ${ }^{27}$ Law provides much needed guidance, especially for those who cannot perceive the ultimate truth. ${ }^{27}$ While he argues that another gift from God is "the power of legislation through the exercise of individual judgement," Ibn 'Arabi's belief that society is as God willed it can be interpreted as a tacit acceptance of that status quo within political organization. ${ }^{27}$ Ibn 'Arabi's support for the political status quo could be interpreted as a rejection of the women's incorporation into societal power structures. However, 'Arabi’s endorsement for women's political and spiritual equality is remarkably robust.

Despite his acceptance of the extent to which some people hold worldly power over others, Ibn 'Arabi unambiguously emphasizes the absolute spiritual equality of all human beings. Because all people are descendants of Adam, a "single spiritual essence" unites all of humanity. ${ }^{27}$ This belief implies that, as a result of this single spiritual origin, gender must be a secondary and unimportant characteristic. ${ }^{14}$ Indeed Ibn 'Arabi is careful to emphasize that "there is no spiritual qualification conferred on men which is denied women."1 As a doctrine which tends to emphasize spiritual development over all else, Sufism has the potential to challenge claims by political authorities regarding the "natural" or "rightful" supremacy of certain types of people over others. ${ }^{3}$ 'Arabi absolutely fulfills this potential with regard to his assertions about the equal spiritual capacities of women.

Further, while Islamic orthodox theology after the $11^{\text {th }}$ and $12^{\text {th }}$ centuries increasingly emphasized the danger inherent in women's sexuality, Ibn 'Arabi's cosmological beliefs offer a powerful counterargument to the way theological convention tends to disassociate women from divinity. ${ }^{5}$ Monotheistic religions, including Islam, often conceive of the universe as a dichotomy between the material, worldly reality and a nonmaterial, divine plane of existence. This worldview values the transcendent reality of God, spirituality and intellect over experienced, physical existence. At the same time, patriarchal ideology regards male as the 
ideal human, with the capacity to transcend nature, emotion and sexuality. As Simone de Beauvoir famously articulated, women are 'othered' by patriarchal discourse, and associated with the lower form of existence that constitutes nature. ${ }^{29}$ The hierarchy between material and nonmaterial reality connects male humans with intellect, spirituality and divinity, while female humans become relegated to the less valued realm of nature and corporeal existence. As a result, religious doctrine interpreted by and for men often assumes that women and spirituality are fundamentally incompatible. ${ }^{30}$ Ascetic practice is especially prone to reject and devalue women, just as it rejects nature and bodily experience in an attempt to reach God. As Ahmed has argued, a great deal of Medieval Islamic theology definitively accepted this formulation, especially in its unyielding advocacy for women's veiling and seclusion. ${ }^{4}$ The Islamic legal tradition often restricted women's movements in order to protect men from temptation and sin. AlGhazali demonstrates a significant amount of concern for women's ability to distract men from God through sexuality. ${ }^{21}$

However, by rejecting a material/nonmaterial dichotomy within his beliefs about the nature of being, Ibn 'Arabi also implicitly rejects much of the misogyny that results from associating women with a lower form of existence. Ibn 'Arabi's cosmology asserts a Oneness of Being principle, wherein God's Essence emanates from God and manifests in creation. God, as the only unchanging presence, represents true, unchanging Being. Everything else in the cosmos is in flux, existing partially in Being and partially in Nonbeing. ${ }^{12}$ Because the universe derives its existence from God, every created being shares in the Essence of God. Therefore, the material world is not, as more orthodox theologians have claimed, radically separate from an unknowable and transcendent God. ${ }^{27}$ Instead, for Ibn Arabi, the created universe is a mirror for God, in which God can contemplate God's own image. ${ }^{27}$ The cosmos is nothing other than God's self-manifestation. As 'Arabi notes, "there is naught but He."27 As a result, the natural world is essentially good and part of God. One cannot understand God without understanding God's creation. Ibn 'Arabi criticizes the theology of al-Ghazali directly on this point, arguing that "certain sages, among them Abu Hamid al-Ghazali, have asserted that God can be known without any reference to the created cosmos, but this is mistaken." 27 God is part of creation, and creation is part of God. For Ibn 'Arabi, "the truth is that the Reality [God] is manifest in every created being and in every concept." 27

Because the created universe is part of God, the material world and nature should not be rejected. Although Ibn 'Arabi, like many thinkers in a male-dominated world, associates women with passivity and with nature, his appreciation of nature itself means that he avoids the extreme misogyny often prevalent in the opinions of ascetics attempting to transcend the natural world. Ibn 'Arabi's admiration of God's creation, as well as his admiration of the feminine aspects of the created world, are evident in his writings. In his theory of cosmology, 'Arabi believes that the masculine Spirit is the spark of life, but without the passive receptivity of the feminine Nature, no life could exist. ${ }^{27}$ While Spirit rules Nature, both are necessary for existence, and both result from the emanation of God's being. In his words, the earth "gives all of the benefits from her essence and is the location of all the good" and as a result, "she is the most powerful of bodies." He recognizes the power and the value within the natural world. For Ibn "Arabi, the earth was created by God, "brought into existence upon His own form" and therefore is "beautiful in the extreme; there is no ugliness in it." 31 If the natural world was made in the image of God, it is not to be transcended, conquered, or rejected. Similarly, because Ibn 'Arabi conceives of nature in feminine terms, femininity is also not something to be transcended and rejected. Ultimately, Ibn 'Arabi does not associate femininity with distance from God because he does not believe in the concept of distance from God.

Ibn 'Arabi's admiration of the natural world lends itself toward a positive view of human sexuality. He has no desire to reject the human body in an attempt to get closer to God. Instead, 'Arabi believes that knowledge of God can be gained through use of the body. ${ }^{1} \mathrm{He}$ claims that "the soul loves the body because all of her knowledge of the Truth is gained through her imprisonment in the body and through her making use of it in order to serve God."1 As a result, humans are superior to the angels, who live in a purely spiritual realm, because humans have physical existence. In the words of Ibn 'Arabi, humanity "harmoniously embraces and incorporates physical, spiritual, emotional, and mental realms, which together function as instrumental in giving humanity its unique station, the possibilities of becoming the most complete mirror of the divine."' The body, for 'Arabi, is vital to the human experience, and to humanity's experience with God.

Theologians within patriarchal traditions often assume that the spirit and intellect, associated with masculinity, are limited and opposed by the emotions and sexuality, associated with femininity. ${ }^{32}$ However, by rejecting the hierarchy of spirituality over nature, Ibn 'Arabi disputes assumptions regarding the corrupting force of female sexuality to male devotion. Indeed for 'Arabi, sexuality is an important part of religious experience. When both partners recognize the divine image in each other, and are aware of the fact that all pleasure ultimately comes from God, then the self-annihilation brought about through absorption in the sexual act is a way for humans to contemplate God. ${ }^{33}$ Accordingly, sex is "the most complete union possible in love, and there is in the elemental sphere no greater union than that between the sexes." 27 The ablution which Islamic tradition requires after intercourse is not, for 'Arabi, a ritual cleansing after an unclean act, but is required because God becomes jealous that anyone finds pleasure in anything but God. ${ }^{27}$ Further, 'Arabi notes that women's bodies are not shameful, and that veiling is for modesty only. ${ }^{1}$ If sexuality is only another method by which one worships God, then women's sexuality is an aspect of religious experience, not a threat to men's relationship with God. Women are not a threat to divinity, or male piety, but are fellow humans capable of participating in 
this type of worship. As a result, Ibn 'Arabi never adopts an accusatory narrative, wherein the sexuality of women is responsible for men's temptation into sin.

Because Ibn 'Arabi does not assume sexuality and spirituality are opposing forces comparable to darkness and light, he implicitly challenges a system of thought which assumes that female sexuality is incompatible with female piety. ${ }^{34}$ When 'Arabi defends one of his female disciples against accusations of sexual misconduct, emphasizing that she was "untouched by suspicion, chaste," he seems to tacitly accept the idea that female sexuality and spirituality are opposed. ${ }^{31}$ However, Shaikh argues that he shows awareness of the "predilection for vicious targeting of Sufi women of superior spiritual character that is so characteristic of patriarchal fury and envy." "Arabi may have conceived of sexuality as a virtuous part of human existence, but he lived in the real world, and knew threats to a woman's sexual reputation amounted to a threat to her spiritual authority. To be clear, 'Arabi absolutely idealizes female virginity. He places a great deal of importance on the virginity of Mary, suggesting that, when Mary first refused Gabriel because she thought he was a human wanting to have sex, she earned the approval of God. ${ }^{27}$ However, for 'Arabi, a woman can embody both sexuality and superior spiritual achievement. This is evident in his portrayal of the Persian Sufi Nizam bint Makin al-Din. Sadiyya Shaikh remarks that Ibn 'Arabi admires her, not only her spiritual achievements and wisdom, but also her beauty and sensuality. ${ }^{1}$ Nizam inspired Ibn 'Arabi's book of love poetry, the Tarjuman al-Ashwaq (The Interpreter of Desires). The Sufi insisted, after being accused of eroticism, that the erotic poetry in the Tarjuman should be interpreted as a metaphor for mysticism. ${ }^{1}$ However, Ibn 'Arabi's poetry and much of his writing fail to make a clear distinction between sexual and mystical experience, suggesting that he did not see one. ${ }^{35}$ His belief system implies that, just as a truly pious human life incorporates both spirituality and sexuality, so too can a woman embody both spiritual and sexual desire.

Unfortunately, Ibn 'Arabi's cosmological belief system does not always lend itself towards gender equality. In his theory of creation, 'Arabi states that just as man was created from God's essence, woman was created from man's essence. Woman's existence is secondary to, and dependent on, that of man. Therefore, woman longs for man in the same way man longs for God, "as one longs for that place to which one belongs."27 Because woman's existence emanated from man in the same way man emanated from God, the best way for a man to contemplate God is by contemplating woman. When a man looks at a woman, he can better understand God, because he embodies active creation in relation to her. ${ }^{27}$ As Shaikh has noted, this paradigm lends itself towards a theological hierarchy of being, wherein man's existence is prior and superior to that of woman. ${ }^{1}$ While Ibn 'Arabi warns against self-deification elsewhere, his theory of creation implies that man is to woman what God is to man. ${ }^{27}$ Further, and perhaps more insidiously, Ibn 'Arabi, similar to al-Ghazali, seems to recommend that men use women as tools for spiritual development. Although 'Arabi warns that any man who interacts with a woman for his own pleasure without recognizing divine essence in her misses the point, this theology might lead to an idealization of the female form without recognition of real women's spiritual needs. Nevertheless, because Ibn 'Arabi believes divinity is best contemplated in woman, he avoids much of the misogyny that characterizes women as antithetical to God.

Further, Ibn 'Arabi suggests that women and femininity hold a special position in the divine order of the universe. As Henry Corbin famously illustrated, Ibn 'Arabi refers to the most powerful aspect God, namely Mercy, in feminine terms." Ibn 'Arabi also notes that in the prophetic saying, "three things have been made beloved to me in this world: women, perfume, and prayer," Muhammad used feminine thalath, not masculine thalathah, to denote the number three. This grammatical choice, to Ibn 'Arabi, suggests that the Prophet gave "precedence to the feminine over the masculine, intending to convey thereby a special concern with and experience of women." 27 Similarly, "Arabi observes that feminine terms are prominent in every school of Islamic thought. ${ }^{27}$ While he does not go on to draw any conclusions from such an observation, Ibn 'Arabi's concern for recognizing femininity within the divine is significant. For 'Arabi, neither God nor human religious experience can be defined on exclusively male terms.

Theologies which make use of feminine metaphors to understand God do not necessarily recognize the value of human women. ${ }^{30}$ Indeed female representations of wisdom are often used as narrative tools for men to convey a particular story. ${ }^{36} \mathrm{However}$, Ibn 'Arabi absolutely advocates for women's right to have a voice in human society. As Sadiyya Shaikh has thoroughly explained, Ibn 'Arabi asserts not only the spiritual equality of men and women, but also advocates for equal treatment in law and society. ${ }^{1}$ Women can reach the highest level of sainthood, speak as an imam before a congregation, and share legal obligations equal to men. "Arabi even claims that "there is nothing in the created universe greater in power than women." ${ }^{1}$ He believes that the Qur'anic story in which the Prophet calls on God, all of the righteous believers, and the angels to counter the strength of 'Aisha and Hafsa, does not demonstrate the folly of these two women, but their strength. ${ }^{1}$ As 'Arabi notes, "all of this is to counter the strength of two women." Therefore, women's strength must be significant. Clearly Ibn 'Arabi was remarkably progressive in his support for women's right to participate fully in both religious experience and human society. 


\section{CONCLUSIONS}

Ibn 'Arabi represents the level of subversion Sufi thought could attain when allowed to flourish without appropriation by orthodox theology or political leaders interested in preserving the status quo. His formative experiences with female mystics, his willingness to challenge traditional orthodoxy, and his Oneness of Being theology all help explain Ibn 'Arabi's remarkable support for gender equality. Ultimately, Ibn 'Arabi's Sufi thought successfully used the authority behind mystical experience to challenge patriarchy. Al-Ghazali, by contrast, used his authority as a Sufi master to reinforce normative gender power dynamics in his society. For al-Ghazali, truly devout Muslim men and women are those who perpetuate a system which oppresses and devalues women.

As has been noted by Sadiyya Shaikh, mysticism itself is comparable to feminism, in that it deconstructs human epistemologies which value the external characteristics of humanity over spiritual and intellectual abilities. ${ }^{1}$ Sufi mysticism has the power and the potential to challenge the traditional notion that patriarchy is inevitable and divinely ordained. However, mystical experience has never occurred in a vacuum. The way mystics understand and experience God and the world around them is dependent on the cultural context in which they live. Sufi thought, therefore, was never exempt from the androcentric ideologies which permeated much of Islamic theology throughout the Medieval period. Further, mysticism can include a fixation on transcendent ecstasy, which often becomes only another attempt by a patriarchal culture to abandon the body. ${ }^{2}$ Sufism could be used as a powerful tool to reinforce both established gender norms and established political rule, or it could be used to validate calls for gender equality and justice.

Medieval Islamic Sufism provides a fascinating medium through which historians can study interaction and conflict between patriarchy and egalitarianism, between established religious authority and individual experiences of God, and between traditional orthodox theology and direct connection to the divine. Despite ideas which appear prevalent in Western media, Islam is not inherently antithetical to gender equality or to justice for women. A great number of writings exist within the Islamic tradition which sanction and approve gender equality. As the study of gender within Islam continues to progress, shedding more orientalist influences and ideas, it will gain more accurate representations of the experiences of Muslim women and men within their own culture. Ultimately Islam is, like any other religion, only what the people who practice it make of it. One can either use religious authority to enforce justice and compassion for all people, or one can use it to perpetuate existing institutions of political power which often devalue women.

\section{REFERENCES}

1. Shaikh, S. (2012) Sufi Narratives of Intimacy: Ibn 'Arabi, Gender, and Sexuality, pp. 13, 42, 82-105, 129, 133-138, 167, 183, 225, 231, University of North Carolina Press, Chapel Hill.

2. Sölle, D. (2001) Definitions, Methods, Delimitations, in The Silent Cry: Mysticism and Resistance, Forty Press, Minneapolis.

3. Schimmel, A. (1975) Mystical Dimensions of Islam, pp. 85, 426-428, University of North Carolina Press, Chapel Hill.

4. Ahmed, L. (2010) Women and Gender in Islam: Historical Roots of a Modern Debate, pp. 53, 60, 84-87, 100, Harvard University Press, Cambridge.

5. Ali, K. (2010) Marriage and Slavery in Early Islam, pp. 15, 47, 114, Harvard University Press, Cambridge.

6. Holmes Katz, M. (2014) Women in the Mosque: A History of Legal Thought and Social Practice, pp. 11, 104, 123, 149, Columbia University Press, New York.

7. Schimmel, A. (1982) Women in Mystical Islam, in Women and Islam, pp. 1-30, Pergamon Press, Oxford.

8. Smith, M. (2001) Muslim Women Mystics, pp. 1-47, Oneworld Publications, Oxford.

9. Murata, S. (1992) The Tao of Islam: A sourcebook on gender relationships in Islamic thought, pp. 3, 14, State University of New York Press, Albany.

10. Griffel, F. (2009) Al-Ghazali’s Philosophical Theology, 35, 40, 43, 48, Oxford University Press, Oxford: Oxford University Press.

11. Corbin, H., (1969) Alone with the Alone: Creative Imagination in the Sufism of Ibn 'Arabi, pp. 157-159, Princeton University Press, Princeton.

12. Chittick, W.C. (1989) The Sufi Path of Knowledge: Ibn al-'Arabi’s Metaphysics of Imagination, pp. 6, 77, 96, State University of New York Press, Albany.

13. Abramahov, B. (2014) Ibn al-'Arabi and the Sufis Anqa Publishing, Oxford.

14. McAuley, D.E. (2012) Ibn 'Arabi's Mystical Poetics, University of Oxford Press, Oxford.

15. Addas, C. (1993) Quest for the Red Sulphur: The Life of Ibn 'Arabi, The Islamic Texts Society, Cambridge.

16. Dabashi, H. (1993) Historical Conditions of Persian Sufism During the Seljuk Period, in Classical Persian Sufism: from its Origins to Rumi, pp. 139 -143, 161, Kaniqahi Nimatullahi Publications, London.

17. Alexander Knysh, Islamic Mysticism: A Short History (Leiden: Brill, 1999), 116. 
18. Nasr, S.H. (1993) The Rise and Development of Persian Sufism, in Classical Persian Sufism: From its Origins to Rumi, pp. 15, Kaniqahi Nimatullahi Publications, London.

19. Karamustafa, A.T. (2007) Sufism: The Formative Period, pp. 113, University of California Press, Berkeley.

20. Schimmel, A. (1999) My Soul is a Woman: The Feminine in Islam, pp. 42, 45, Continuum, New York.

21. Al-Ghazali, A.H., Ihya' Ulum al-Din, trans. Farah, M. (2012) Marriage and Sexuality in Islam, in Revival of Religions Sciences, Islamic Book Trust, Selangor.

22. Avila, M.L. (2002) Women in Andalusi Biographical Sources, in Writing the Feminine: Women in Arabic Sources, I.B. Tauris Publishers, London

23. Viguera Molins, M.J. (2002) A Borrowed Space: Andalusi and Maghribi Women in Chronicles, in Writing the Feminine: Women in Arabic Sources, I.B. Tauris Publishers, London.

24. Addas, C. (1992) Andalusi Mysticism and the Rise of Ibn 'Arabi, in The Legacy of Muslim Spain, pp. 910, 928, E.J. Brill, New York.

25. Chodkiewicz, M. (1993) Seal of the Saints: Prophethood and Sainthood in the Doctrine of Ibn 'Arabi, pp. 14, Islamic Texts Society, Cambridge.

26. Abū 'Abd Allāh Muḥammad ibn 'Alī ibn Muḥammad al-Ḥātimī aṭ-Ṭā' ̄̄ ibn 'Arabi, Ruh al-quds, trans., Austin, R.W.J. (1971) Sufis of Andalusia, pp. 142-155, University of California Press, Berkeley and Los Angeles.

27. Abū 'Abd Allāh Muḥammad ibn 'Alī ibn Muḥammad al-Ḥātimī aṭ-Ṭā' 'ì ibn 'Arabi, Fusus al- Hikam, trans. Austin, R.W.J. (1980) Bezels of Wisdom, pp. 50, 54, 57, 74, 77-80, 87, 92-93, 98-103, 132, 137, 168, 175, 213, 247-266, 274-278, Paulist Press, Inc., New Jersey.

28. Abū 'Abd Allāh Muḥammad ibn 'Al̄̄ ibn Muḥammad al-Ḥātimī aṭ-Ṭầ' ì ibn 'Arabi, trans. Nicholson, R.A. (1911) Tarjuman al-Ashwaq: A collection of mystical odes, pp. 49, Royal Asiatic Society, London.

29. De Beauvoir, S. (1949) The Second Sex, 1949, trans. Constance Borde and Sheila Malovaney-Chevallier (2011) Random House Inc., New York.

30. Hein, Hilde (1989) Liberating Philosophy: An End to the Dichotomy of Spirit and Matter, in Women, Knowledge, and Reality: Explorations in Feminist Philosophy, pp. 293, Routledge, New York and London.

31. Ibn 'Arabi, Al-Futuhat al-makkiyya, trans. Chodkiewicz, M., Chittick, W.C., and Morris, J.W. (2004) The Meccan Revelations, pp. 182, Pir Press, New York.

32. Carr, A. (1988) Transforming Grace: Christian Tradition and Women's Experiences, pp. 177, Harper and Row, San Francisco.

33. Derin, S. (2012) Earthy and Spiritual Love in Sufism: Ibn 'Arabi and the Poetry of Rumi, in Love and Devotion: From Persia and Beyond, pp. 58, Macmillan Art Publishing, Oxford.

34. Lerner, G. (1986) The Creation of Patriarchy, Oxford University Press, New York.

35. Lutfi, H. (1985) The Feminine Element in Ibn 'Arabi's Mystical Philosophy, Journal of Comparative Poetics 5, pp. 7-

36. Clark, E.A. (1998) The Lady Vanishes: Dilemmas of a Feminist Historian after the 'Linguistic Turn,' Church History 67, no. 1, pp. 1-31.

\section{ABOUT THE STUDENT AUTHOR}

Emily Dovel graduated from the University of Portland in 2016 with a Bachelor of Arts in History, and minors in Gender and Women's Studies and Political Science. She had received a Fulbright Grant to teach English in Turkey for the 2016-2017 school year. However, after the United States Department of State canceled the Fulbright ETA Grants to Turkey, Emily instead enrolled in an intensive Arabic language program at the Qalam wa Lawh Center for Arabic Studies in Rabat. Emily plans to continue to work towards fluency in Arabic before entering a PhD program in Middle Eastern History.

\section{PRESS SUMMARY}

This article examines the ways in which the political contexts and theological beliefs of two prominent Sufi mystics represent gender ideology within medieval Islamic societies. Al-Ghazali, a theologically conservative Sufi, who also lived under the enormous political pressures of Seljuk rule, uses his Sufism to reinforce traditional gender norms. Ibn 'Arabi, by contrast, was largely free from the political and theological pressures of dominant institutions, and was therefore free to use his theological beliefs to advocate gender equality. The ways in which prominent religious figures in Islamic history perceived gender and sexuality can help modern people to better understand gender ideology in the Islamic world today. 